\title{
Inscribing the city: a flâneur in Tokyo
}

\author{
By Raymond Lucas (Department of Anthropology, University of \\ Aberdeen).
}

A recent topic for fascination in architectural theory has been Walter Benjamin's work on the flâneur of Charles Baudelaire's Paris. This figure, more than just a wanderer, shopper or tourist, characterises one aspect of the modern city-dweller's condition, as found in the Parisian arcades. This meandering, aimless 'Man Without Qualities' so informs how we understand the city, for example, as a prototype for both the cinematic subject and audience. Flânerie also has its uses as a thinking tool. City-based artistic movements in the 20th century, from the Dada and Surrealists through to Fluxus and the Situationists have all exploited similar modes of distracted attention in traversing the city. This trajectory takes us to the Situationist International in particular, who engaged with the city in a fashion analogous to the paper support for a drawing, equip us with new ways of understanding the experience of the city. As a part of my general inquiry into the role of drawing and notation in creative practice, the graphic representation of the city forms a case-study of particular interest. How do these alternatives to the traditional tools of architecture and urbanism aid or reconfigure our understandings of cities? This final section shall outline some of my own working practices. Drawn from the tradition of the architectural fantasy, which traces its history from Piranesi through Ferriss and Constant to Tschumi, Koolhaas and MVRDV. By considering architecture as a practice of representation as well as of space- and place-making, the architectural fantasy or paper project offers distinctive possibilities beyond what is commonly assumed to be simply an 'unbuilt' or 'unbuildable' project. As such, I place my reflections upon Tokyo into this tradition - I will explore the process I have worked through in representing a journey taken through Shinjuku station.

\section{On the fascination of the flâneur}

It is not given to every man to take a bath of multitude; enjoying a crowd is an art; and only he can relish a debauch of vitality at the expense of the human species, on whom, in his cradle, a fairy has bestowed the love of masks and masquerading, the hate of home, and the passion for roaming. Baudelaire, C. 'Crowds'. (1970: 20)

Paris created the type of the flâneur. What is remarkable is that it wasn't Rome. And the reason? Does not dreaming itself take the high road in Rome? And isn't that city too full of temples, enclosed squares, national shrines, to be able to enter tout entiere - with every cobblestone, every shop sign, every step, and every gateway - into the passer-bys' dream? The national character of the Italians may also have much to do with this. For it is not the foreigners but they themselves, the Parisians, who have made Paris the promised land of the flâneur- the landscape built of sheer life, as Hoffmansthal once put it. Landscape - that, in fact, is what Paris 
becomes for the flâneur. Or, more precisely: the city splits for him into its dialectical poles. It opens up to him as a landscape, even as it closes around him as a room. Benjamin, W. (1999a: 417)

In this paper I use the city to develop a theory of inscriptive practices, particularly sketching, drawing and notation as 'thinking tools' that extend and run parallel to theoretical text. By reconfiguring the city through drawing and notation,we can begin to understand it better than by simply representing it. The aim of this project has been both to understand an event from my activities as a flâneur in Tokyo, and also to reflect upon this process of reconfiguration. The work is part of the larger AHRB research group 'Creativity and Practice' based in the department of anthropology in the University of Aberdeen and the School of Fine Art at Duncan of Jordanstone at the University of Dundee. I come from a background in architecture, so drawing is already an important part of my practice, and one which I already understand to be capable of exploring theory.

As a methodology, I have established a series of experiments. These have involved transcribing cinema scenes and real events, using sketch, drawing, notation and varieties of approaches to help my understanding of inscription and transcription as processes. Each of these cannot be a wholly reflexive enterprise, in that you cannot simply draw about drawing - so each project has taken on aspects of other concerns, such as the permeability of inscription as a translation from one discipline to another. As such, the series of drawings has addressed cinema, movement, events such as a sumo match, and, as we shall see below, the city. I aim also to show that these choices of events are not accidental, but express issues to the benefit of my overall project: to understand inscriptive practices as creative modes of thinking rather than ways of expressing a pre-formed idea.

Talking about the city in isolation of those who inhabit its territories is a common criticism of architectural and urban theory, especially at the height or modernism and the International Style. The early roots of what we now know as 'modernism', however, had a strong humanist element. Charles Baudelaire, writing just at the cusp of modernism's beginnings, and later, Walter Benjamin, writing in its early phase, both identified with the urban character by the name of the flâneur. Baudelaire spoke movingly of how this character was vanishing in his time, as a result of Baron Haussmann's boulevards, in opposition and competition with the arcades; which were the native haunts, or hunting grounds of the flâneur. By the time Benjamin wrote about the flâneur, however, we have seen the transformation of Paris into a city of boulevards, with the arcades only just surviving as a partly hidden route running North to South of the right bank. Benjamin finds this character interesting and relevant, as have many since.

The leisurely quality of these descriptions fits the style of the flâneur who goes botanizing on the asphalt. But even in those days it was not possible to stroll about everywhere in the city. Before Haussmann wide pavements were rare, and the narrow ones afforded little protection from vehicles. Strolling could hardly have assumed the importance it did without the arcades. Benjamin (1997: 36)

Tim Ingold (2003), drawing on Eric Havelock and Andre Leroi-Gourhain, suggests that different models of reading exist within the medieval and modern mind. The model of the medieval reader is similar to that of a hunter-gatherer, a reader who seeks out meaning in a text, who tracks its smallest signs and identifies trails within the text. Whilst this model still persists in literature to this day, the majority of the 
admittedly much larger body of written texts are now aimed at readers who expect the progression of information in an orderly, chronological manner of reportage. This suggests a difference in the activity of reading between literature and popular fiction, or investigative journalism and that of the tabloid media. Meaning in this model, which emerged with modernity, is imparted rather than found. These models of spectatorship as active or passive can be found in many other disciplines. The cinema, for example, has spectatorship theory centred around the idea of an active spectator who can create meaning for themselves; and also has theory centred on the passive recipient who is sutured into their entertainment. Put simply, the difference between so-called art-cinema and movies. This dichotomy of spectatorship exists in other art forms as well - the fine arts, architecture, music. It should come as no surprise, then, that the city can be modeled similarly, opposing the flâneur and his ilk to the shopper, the tourist, or the commuter.

Basic to flânerie, among other things, is the idea that the fruits of idleness are more precious than the fruits of labour. The flâneur, as is well known, makes studies. On this subject, the nineteenth-century Larousse has the following to say: His eyes open, his ear ready, searching for something entirely different from what the crowd gathers to see. A word dropped by chance will reveal to him one of those character traits that cannot be invented and that must be drawn directly from life; most men of genius were great flâneurs but industrious, productive flâneurs. Benjamin (1999a: 454)

How, then, is the flâneur said to see the city? Here we can turn to Benjamin in his extended studies of the character, related to his reading of Charles Baudelaire. Benjamin's major unfinished work, The Arcades Project, devotes an entire section to the flâneur; Convolute M: 'The Flâneur' (Benjamin 1999a: 417-455). This places the flâneur alongside such phenomena as fashion (Convolute B); iron construction (Convolute F); prostitution, gambling (Convolute $\mathrm{O}$ ); and photography (Convolute Y); indeed, the flâneur is understood as a phenomenon.

Preformed in the figure of the flâneur is that of the detective. The flâneur required a social legitimation of his habitus. It suited him very well to see his indolence presented as a plausible front, behind which, in reality, hides the riveted attention of an observer who will not let the unsuspecting malefactor out of his sight. Benjamin (1999a: 442)

If one tries to picture this rhythm and investigate this mode of work, it turns out that Baudelaire's flâneur was not a self-portrait of the poet to the extent that this might be assumed. An important trait of the real-life Baudelaire that is, of the man committed to his work, is not part of the portrayal: his absentmindedness. In the flâneur, the joy of watching is triumphant. It can concentrate on observation; the result is the amateur detective. Or it can stagnate in the gaper; then the flâneur has turned into a badaud. The revealing presentations of the big city have come from neither. They were the work of those who have traversed the city absently, as it were, lost in thought or worry. Benjamin (1997: 69)

What, then is the relevance of this figure? This dilettante wanderer is an unlikely hero for a writer associated so strongly with the left, Adorno and the Frankfurt school. The issue at hand is, however, finding the joy and comfort of the urban environment. Far from decrying the modern city as inhuman, Benjamin celebrates its anonymity, the way in which one can be both lost and at home in a crowded street or on public transport. The flâneur is a figure who understands this sheer enjoyability of the 
modern city - the exhilaration, and display, of promenading to see and be seen is all part of the urban character. The flâneur inscribes upon the city: writing rather than reading the city. This is an important distinction, as his spectatorship is an active one, which imposes his will upon the city streets, creating a narrative as he goes along.

\title{
2. Flânerie as a thinking tool
}

Flânerie has long been regarded as a creative tool. Francesco Careri of the Stalker group (an Italian interdisciplinary urban workshop group), in his work Walkscapes: Walking as an Aesthetic Practice (Careri 2002), establishes a trajectory for the use of this notion from the Dada anti-art movement, through Surrealism, the Situationists and Fluxus movements to the work of Robert Smithson and Richard Long. Whilst some of the best documented examples of the use of flânerie as a thinking tool are found in the works of the Situationist International and the notion of drive or drift.

\begin{abstract}
Among the various situationist methods is the drive, a technique of transient passage through varied ambiences. The dérive entails playfulconstructive behaviour and an awareness of psychogeographical effects; which completely distinguishes it from the classical notions of the journey and the stroll.

In a dérive one or more persons during a certain period drop their usual motives for movement and action, their relations, their work and leisure activities, and let themselves be drawn by the attractions of the terrain and the encounters they find there. The element of chance is less determinant than one might think: from dérive point of view cities have a psychogeographical relief, with constant currents, fixed points and vortexes which strongly discourage entry into or exit from certain zones. Debord, G. Theory of the Dérive. From Andreotti \& Costa Eds.(1996: 22)
\end{abstract}

The Situationist drifting strategy is closely tied to their notion of 'Psychogeography'. This notion seeks to explore the hidden, non-physical connections between spaces, as well as to chart the patterns of desire within a space. Several examples of Psychogeographic maps were produced by the group, most notably The Naked City (1957) by Guy Debord and Asger Jorn in which patches of a map of Paris are collaged with variously sized arrows including images of war and colonialism, postage stamps and the text reading 'Life continues to be free and easy'. Each map represents a drift taken by Debord and his colleagues through Paris - a series of connections that cannot be adequately represented on a standard plan of the city. This drifting strategy is clearly related to flânerie as defined by Benjamin. The non-random nature of the movement asserted by Debord is important, as it is determined by various attractions and spectacles and how these act upon the drifter. It is a similar action of traversing urban space that I undertake in Tokyo and the accompanying notations and drawings are largely the result of the various attractions and repulsions of the journey through Shinjuku station.

The theory of the dérive informed much of the work of the Situationist International and beyond. An example is the work of the artist/architect Constant. Constant took the central theme of the drift, and incorporated it into his attempts to create a unitary urbanism based upon a view of the future where humanity would be released from the burdens of work and accordingly was free to play however and whenever desired. This informed his plans and models for New Babylon - a proposition for a Situationist city, where the entire structure could reconfigure according to the whims 
of the New Babylonians. De Zegher \& Wigley (2001) as well as Wigley (1998) detail this project as well as its aims and implications in great detail. Indeed, from an architectonic perspective the intent behind the project is of greater interest than the megalithic structures that harken to the greatest excesses of modernism rather than railing against them, as was intended by Constant himself.

As mentioned earlier, this is placed against the Dadaist excursions to banal places, the Surrealist reconfiguration of the city through games, and Fluxus street-theatre and happenings. Such aesthetic and creative implications for flânerie and similar wayfaring occur quite differently in urban situations from wilderness situations, such as those explored by Richard Long. The sense of isolation in the city is of an entirely different quality to that found in the wilderness, a quality which lies beyond the scope of this work.

The wilderness walk degrades and fades with the passing of time, whilst the urban walk perpetuates its memory in the walkers and those traces left behind, be they representations, reconfigured maps, or the memories of participants who may or may not have been passers-by. The apparatus of memory and interaction with others not aware of, or not implicated in your action define some of the key differences in the urban walk. After all the flâneur walks to be observed, as well as to observe others.

\section{Methodology: getting lost in Tokyo}

With this project, I have placed my work alongside that of the architectural fantasy i.e. a paper project that is never meant to be realised. Such works demand a view of architecture as a discipline that moves beyond the built, and allows the product of architecture to include theory, drawing and other models. This mode of working has a long and influential history.

Since the mid- $20^{\text {th }}$ century, architectural works such as those by Bernard Tschumi (1994), John Hejduk (1986), Koolhaas (1994), Archigram (Cook 1991) and MVRDV (1998) have moved architectural theory and practice in distinct directions, despite the unbuilt or unbuildable nature of the product. Architecture as an academic endeavour is more than simply building - engineers and the construction industry can and do build without architects, after all.

The work to which I shall refer is entitled 'Getting Lost in Tokyo', (Lucas 2003) and is derived from a short trip to the city in January of 2003. The project takes one event, which was iterative in nature - repeated a number of times, and rendered as a flowchart diagram. The event chosen was the negotiation of Shinjuku Station, a large subway and railway hub, consisting of over 40 exits, two major department stores and many of the other conveniences and advertising associated with Tokyo subway stations.

This event was taken both from memory, and from written and drawn notes taken at the time recording the experience. The apparatus of memory and its influence on the experience is an important consideration, of course. This event is taken from the point of view not of a commuter - the normal inhabitant of Shinjuku Station (especially in the legendary rush-hour crushes), but of the traveller, wanderer, wayfarer or flâneur. 


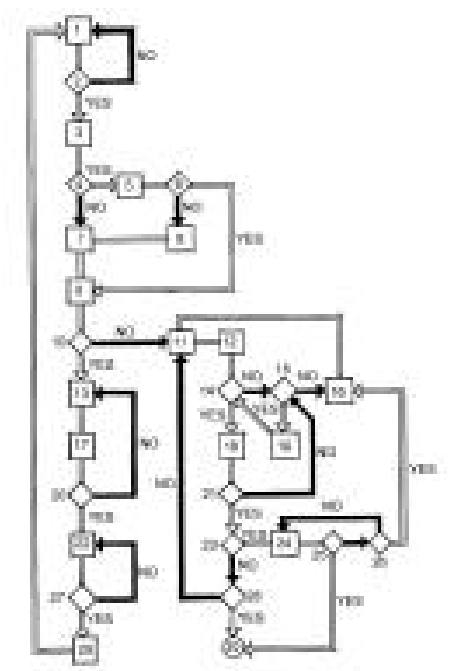

Figure 1: the flowchart diagram.

The first diagram, a flowchart, renders the experience in small slices, similar to the montage of a film (indeed, many events could be seen as distinct in one sense, but also as occurring simultaneously with other events or even nesting within each other). With these divisions, I looked at each part of the event again, and worked on a simple phrase using Laban notation (a form of movement notation frequently used in ballet, but designed and suited for use in many other activities and which enlarged upon the simple phrases of the flowchart in a qualitative manner). From this, I began to work with architectural drawings, specifically the axonometric; a form of drawing made by projecting from the plan upwards and thus creating a three-dimensional representation of space. Such drawings are suited to showing volumes and surfaces, and are objective, as opposed to the subjective viewpoint of a perspective drawing. In order to translate the Laban notation back into architectural space once again, I reworked each element of the Laban into smaller parts, and found analogous forms in drawing. This could be a simple representation of how the body responds to a vibrating subway train whilst standing up - this is shown as a floor made up on irregular steps up and down, and indicating how a body can move but remain static at each position reached before moving on. Combining this element with other parts of the whole Laban phrase created ever more complex drawings.

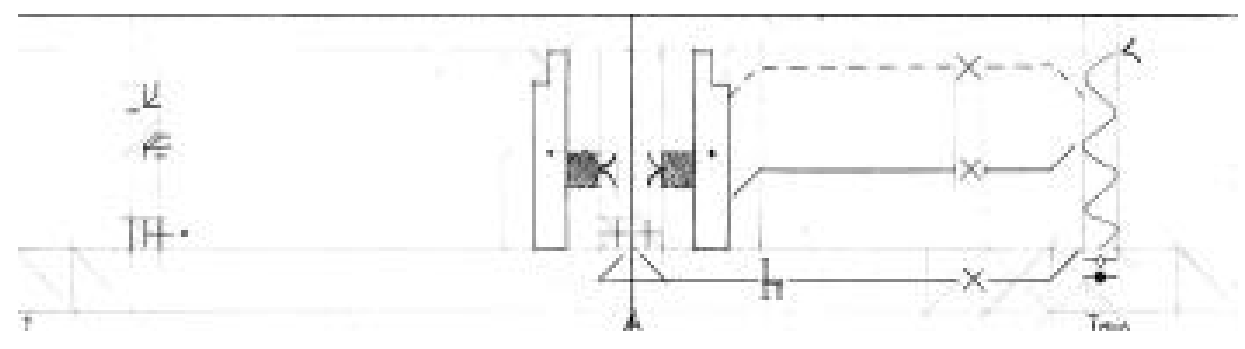

Figure 2: Laban notation. 


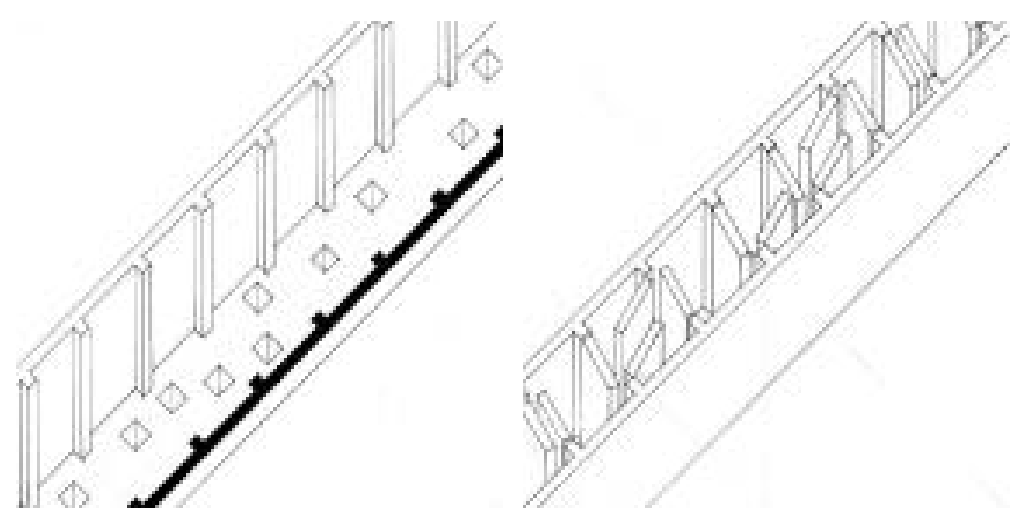

Figure 3: corridor archetype drawings, each based on elements of Laban notation phrasing.

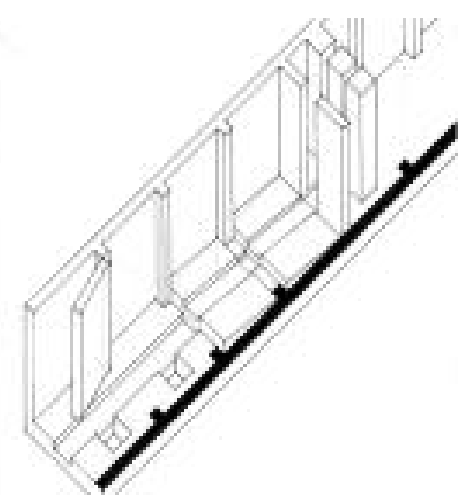

Figure 4: axonometric drawing combining elements of several corridor archetypes.

A further feature of the drawing project incorporated influences from other sources. These included fiction, cinema, images and other sources, which I found had some resonance with the scenes I wished to translate. This part of the exercise helped equip the more direct translation from Laban to axonometric with some of its language. (The process of translation took two months of work at the drawing board and followed a pattern similar to that of the design process in architecture from concept to drawing up). The final assembled pages of the project incorporated the following: the event title drawn from the flowchart; the Laban notation of that event; the axonometric; and a photograph from elsewhere in Tokyo that relates laterally to the event described. Each of the 30 events is then represented by an accumulation of diagram, notation, drawing and photograph - each a different form of image, contributing to a whole. This recalls another key work of Benjamin (Benjamin, W. The Task of the Translator. 1999b: 70); of particular interest is his quotation of Rudolf Pannwitz:

Our translations, even the best ones, proceed from a wrong premise. They want to turn Hindi, Greek, English into German instead of turning German into Hindi, Greek, English. Quoted in Benjamin (1999b: 81)

The above essay from Benjamin suggests some fertile ground for further study of drawing as translation, and the issues raised by it. 
3. Stand up and wait at door
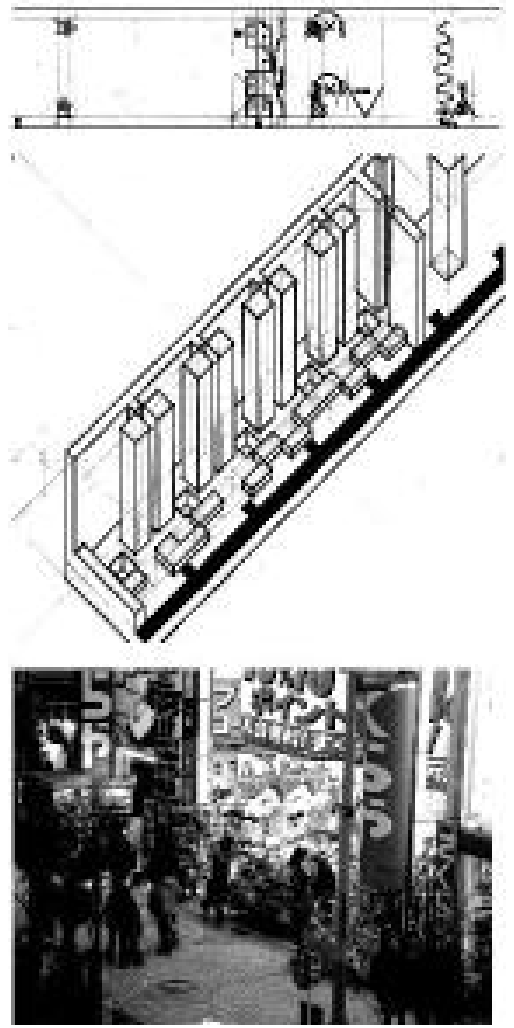

7. Press the door release
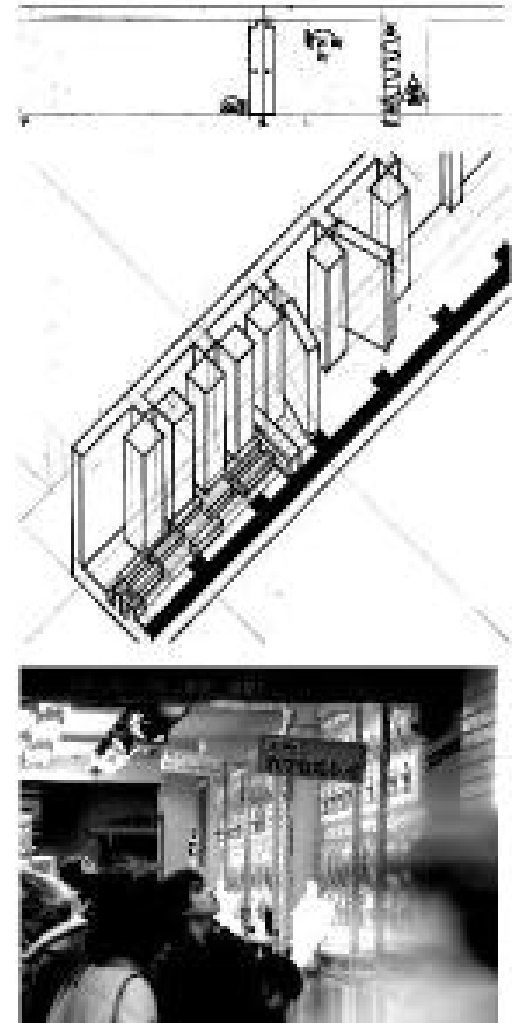

Figure 5: examples of assembled pages with diagram, notation, drawing and photograph.

The photographs suggest a reconfiguration of my experiences over the course of the whole trip - a mapping of Shinjuku Station to other locations across the city such as Asakusa, Odaiba and Meiji Shrine. These photographs respond in multiple ways to the other images on each page - to the flowchart diagram, to the Laban notation and also to the architectural drawing. It is an assembly that recalls the idea of Vertical Montage explored by Sergei Eisenstein (1991:327) and taken on architecturally by Bernard Tschumi (1994). It works in a similar manner to the different musical instruments and sections of an orchestra in contributing to a work of music as an overall composition. The juxtaposition of one element with another, according to Eisenstein, allows for a third image or meaning to emerge. Eisenstein used this principle in a didactic manner but it also contains the potential to be subverted for more poetic expression also, as argued later by Tarkovsky (1986). 

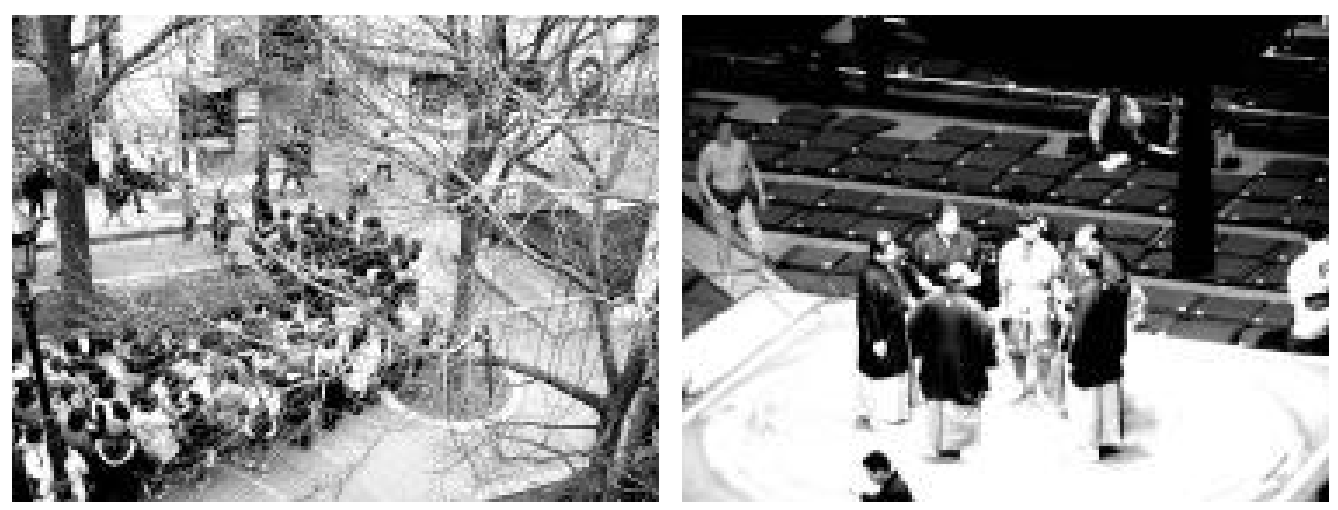

Figure 6: photographic references to analogous conditions found in Tokyo.

The 30 slices of the larger event are organised according to a model derived from an influence not directly connected to the Tokyo flânerie. This model referred to a condition found in Andrey Tarkovsky's film Stalker. This repeated motif, which helped develop the axonometric drawing series, was draws as a labyrinth, specifically in the form of a spiral. The narrative of this film revolves around a territory, which is fraught with dangers, and, despite the destination being clearly visible, a guide with special knowledge called a Stalker is needed to negotiate the implied traps. The drawing shows a spiral labyrinth, with doors indicating shortcuts built into it. Another version of this drawing maintained the spiral form but inscribed it into the ground, thus rather than a maze of walls there is simply an implied route with an obvious destination to all in the centre. This forms the organisational model by which the axonometric renderings of the Laban phrases are placed and once more recalls Benjamin:

The city is the realisation of that ancient dream of humanity, the labyrinth. It is this reality to which the flâneur, without knowing it, devotes himself. Without knowing it; yet nothing is more foolish than the conventional thesis which rationalises his behaviour, and which forms the uncontested basis of that voluminous literature that traces the figure and demeanour of the flâneur the thesis, namely, that the flâneur has made a study of the physiognomic appearance of people in order to discover their nationality and social station, character and destiny, from a perusal of their gait, build and play of features. The interest in concealing the true motives of the flâneur must have been pressing indeed to have occasioned such a shabby thesis. Benjamin (1999a: 429)
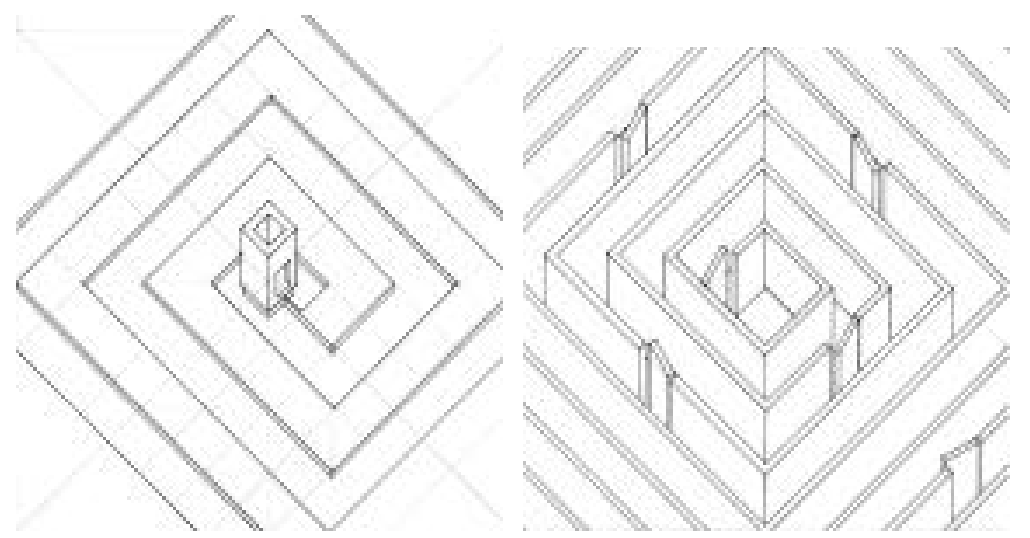

Figure 7: the organisation of the whole according to Tarkovsky's Zone. 
The original aim of this project lies in my thesis, entitled 'Towards a Theory of Notation and Drawing as Thinking Tools'. This work illustrates several of the ideas from that project, where translating from one form of inscription to another adds value at each process. Hence, the organisation of the Shinjuku Station event from the flowchart lends an order to the Laban which would have been impossible to organise without some form of external framework. By the same token, the Laban lends its concerns about movement and the body to the architectural drawing- so that each element responds to the body in a particular way - whereas deriving architecture from the original event might have resulted in such a similarity with that event as to have been a useless exercise. The removal and abstraction by using several filters of inscription was an essential element of the project.

The masses in Baudelaire. They stretch before the flâneur as a veil: they are the newest drug for the solitary. Second, they efface all traces of the individual: they are the newest asylum for the reprobate and the postscript. Finally, within the labyrinth of the city, the masses are the newest and most inscrutable labyrinth. Through them, previously unknown chthonic traits are imprinted on the image of the city. Benjamin (1999a: 447)

With this accumulation of meaning, the more a source is inscribed, what is the result? This interpretation of a distinctly urban event provided me with challenges that other exercises have not. This representation of architecture moves us away from the traditional architectural drawing's concentration upon static fixtures, and renders such things as distraction of attention by advertising and signage; the movement of crowds against and towards your destination, and the way in which you negotiate a space. The task of this drawing series is to understand better the quality of the difference between this use of architectural drawing, as compared to the traditional uses in design and construction. What is also shown through the drawing is that the architectural experience is much more than is normally shown in its representations, including architectural photography, which is normally evacuated of any sign of occupation. By representing other concerns than the play of solid and void, we broaden the scope of what architecture and our experience of the city can be.

Inscribing the city in this way is more than a method to represent the experience. There are more direct ways in which this could have been achieved, for example prose writing or a documentary video. The point of working in this way, through diagram, notation, drawing and photography, was to understand the experience more fully. The inscription, then, is itself a learning process. That learning is understanding in practice is the core premise of the Creativity and Practice research group. This project is one example of this phrase in action.

\section{References}

Andreotti, L \& X Costa Eds. 1996. Theory of the dérive and other Situationist writings on the city. Barcelona: Actar.

Baudelaire, C. 1970. Paris spleen. L. Varèse (Trans.). New York: New Directions.

Benjamin, W. 1997. Charles Baudelaire. H. Zohn (Trans). London: Verso 
Benjamin, W. 1999a. The arcades project. H. Eiland \& K McGlaughlin (Trans.). Cambridge, Massachusetts: Belknap Press of Harvard University Press.

Benjamin, W. 1999b. Illuminations. H. Zorn (Trans.) London: Pimlico

Careri, F. 2002. Walkscapes: walking as an aesthetic practice. Barcelona: Gustavo Gili Land\&Scape Series.

Cook, P (Ed). 1991. Archigram, Basel: Birkhauser Verlage.

Eisenstein, S. 1991. Eisenstein volume 2: towards a theory of montage. Glenny, M \& R Taylor (Eds.) Glenny, M Trans. London: British Film Institute.

Ingold, T. 2003. Lines from the past: towards an anthropological archaeology of inscriptive practices. Rhind Lecture Series, Edinburgh: Society of Antiquaries Scotland.

Hejduk, J. 1986. Victims. London: Architectural Association.

Koolhaas, R. 1994. Delirious New York. New York: Monacelli Press.

Lucas, R 2003. Getting lost in Tokyo. Dundee \& Aberdeen: Creativity and Practice Research Group with the Centre for Artists Books (Forthcoming).

MVRDV. 1998. Costa Iberica. Barcelona: Actar

Tarkovsky, A. 1986. Sculpting in time. Austin, University of Texas Press.

Tschumi, B. 1994. The Manhattan transcripts: theoretical projects. London: Academy Editions.

Wigley, M. 1998. Constant's New Babylon: The hyper-architecture of desire. Rotterdam: 010 Publishers

de Zegher, C \& M Wigley (Eds.). 2001. The activist drawing: retracing Situationist architectures from Constant's New Babylon to beyond. Cambridge, Massachusetts: MIT Press and The Drawing Center, New York.

\section{About the author}

Raymond Lucas is a $\mathrm{PhD}$ researcher with the Creativity and Practice research group based at the Department of Social Anthropology at the University of Aberdeen, where he is supervised by Professor Tim Ingold. This project is an AHRB funded project run jointly by the School of Fine Art at Duncan of Jordanstone in Dundee and the University of Aberdeen. Lucas has a background in architecture, and has recently graduated from the University of Strathclyde's architecture department with an MPhil for the thesis 'Filmic Architecture'. He also worked on the 'John Grierson Multimedia Archive' for SCRAN (Scottish Cultural Resources Access Network). This work included a CDROM and 500 web-accessible records of the life and work of the documentary film pioneer.

Lucas' current research is entitled 'Towards a Theory of Inscription as a Thinking Tool.' Part of this work will result in an exhibition at the VRC's Centrespace Gallery in Dundee in August 2004 entitled 'Getting Lost in Tokyo.' Other forthcoming projects include a publication of the Tokyo drawing series and an exhibition with the Creativity and Practice research group in Aberdeen in 2005. 